\title{
Land Use Land Cover Changes and Encroachment Issues in Kapkatet Wetland, Kenya
}

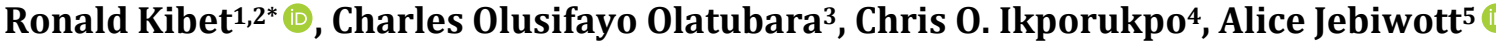 \\ ${ }^{1}$ Department of Environmental Management, Pan African University Life and Earth Sciences Institute (PAULESI), Private Bag, \\ University of Ibadan, Ibadan, Nigeria \\ ${ }^{2}$ Department of Natural Resources and Environmental Science, Kisii University, Kisii, Kenya \\ ${ }^{3}$ Department of Urban and Regional Planning, University of Ibadan, Private Bag, Ibadan, Nigeria \\ ${ }^{4}$ Department of Geography, University of Ibadan, Private Bag, Ibadan, Nigeria \\ ${ }^{5}$ Department of Development Studies, Catholic University of Eastern Africa, Nairobi, Kenya \\ Email: *ronaldlangatkip@gmail.com
}

How to cite this paper: Kibet, R., Olatubara, C.O., Ikporukpo, C.O. and Jebiwott, A. (2021) Land Use Land Cover Changes and Encroachment Issues in Kapkatet Wetland, Kenya. Open Journal of Ecology, 11, 493-506.

https://doi.org/10.4236/oje.2021.117032

Received: January 30, 2021

Accepted: July 11, 2021

Published: July 14, 2021

Copyright $\odot 2021$ by author(s) and Scientific Research Publishing Inc. This work is licensed under the Creative Commons Attribution-NonCommercial International License (CC BY-NC 4.0). http://creativecommons.org/licenses/by-nc/4.0/

\begin{abstract}
Kapkatet Wetland is a vital ecosystem in Kenya that supports rural livelihoods through the provision of various ecological goods and services. However, this ecosystem has been undergoing rapid degradation arising from competing land uses. It's important to document these changes to obtain insights that can aid decision-making for effective restoration and conservation. This study, therefore, sought to assess the extent and patterns of land use and land cover changes in Kapkatet Wetland between 1986 and 2019, and their driving forces. The study followed a mixed-method research approach involving a combination of remote sensing and descriptive surveys. To quantify the wetland changes, remotely sensed imageries for 1986, 2000, and 2019 were utilized in classifying land use and land cover maps through the Maximum Likelihood algorithm. Household questionnaires and focus group discussions were used to obtain information about peoples' perceptions of the driving forces of landscape change within the wetland. Results generally showed that Kapkatet wetland declined by $24.77 \%$ over the past years (1986-2019). Wetland vegetation declined drastically as open grounds increased while tree cover and disturbed reeds showed a fluctuating trend. These changes were majorly driven by land conversion activities within the wetland. The study recommends a community-based enforcement approach to existing laws and policies by both $\mathrm{Na}$ tional and Local governments to curb the continuous loss of this wetland.
\end{abstract}

\section{Keywords}

Wetlands, Land Use/Land Cover, Kapkatet Wetland, Change Detection, 


\section{Introduction}

Wetland biomes are very sensitive to any form of interference emanating either from anthropogenic activities or natural causes. For a very long time, they have been perceived as biomes of little or no ecological value, wastelands [1]. This ideology has contributed significantly to the continuous loss of more than half of the global wetlands' acreages even though they provide diverse ecological and hydrological services [2]. Many of the global wetlands have been drained to pave way for the emerging anthropogenic activities like agricultural and infrastructural developments [3]. Between the years 1993-2007, approximately $6 \%$ of the global wetland acreages were lost due to encroachment [4]. Urbanization has also contributed significantly to encroachment issues like in the case of Jinja-Uganda where a study by [5] found out that industries established in Jinja had been discharging raw effluents into a nearby wetland which negatively impacted the health status of the wetland. The short-term benefits accrued from most of the economic activities carried out within wetlands like crop cultivation have never surpassed goods and services accrued from such ecosystems [2].

Landscape spatial patterns, particularly those of wetlands, are often dynamic owing to intra-annual variations in ecosystem variables, whether driven by natural or anthropogenic influences [6]. Change detection of land use and land cover changes provide a fantastic opportunity to learn more about complex and dynamic ecosystems such as wetlands [7]. Availability of precise and reliable land use and land cover change information is critical for environmental planning for sustainable development as it enhances understanding of the anthropogenic influence on the terrestrial ecosystem [8] [9]. Remote sensing technology has over time been adopted as a tool to detect, identify, measure, assess, and generate information on patterns of land use changes over wetlands in various parts of the world [10] [11]. [12] affirmed that remote sensing approaches can be used to monitor, classify, or manage wetlands. Remote sensing techniques used to classify wetlands include visual inspection and analysis, supervised classification, unsupervised classification, hybrid classification, and principal component analysis [12].

For many years, remote sensing techniques have been used in wetland research around the globe. Synthetic-aperture radar (SAR)-based change detection approach utilizing Sentinel-1 time series was applied in studying landscape changes in two wetlands in Spain and France [7]. The study concluded that it was effective in providing a precise characterization of areas with a lot of fluctuation as well as those with slow and steady changes. Using Landsat imageries, a combination of NDVI and NDWI indices were applied in land cover change detection of Tanguar Haor wetland, a Ramsar site in Bangladesh, in which it was established that about $40 \%$ of land cover under forests and highland vegetation 
had been converted to residential and agricultural land over 30 years period [8]. In Iran, pixel-based change detection was to evaluate land cover changes in the Hamoun Wetland from 1987-2016. Fluctuations water, which is a response to both climatic and anthropogenic factors, was found to be a major determinant of land cover changes [9]. Multispectral ASTER images, classified through artificial neural networks and support vector machine algorithms, were used in performing land use and land cover change detection at Sultan Marshes wetland in Turkey for the period between 2005 and 2012 [12]. The study observed that between 2005 and 2012, marshes and steppe lands shrank, while water and agricultural areas increased. [13] used Landsat imageries in mapping wetland dynamics of Isimangaliso Wetland Park in South Africa. According to their findings, alterations in vegetation and water body extents had exacerbated the Isimangaliso Wetland Park's dramatic decrease in recent years. In Kenya, remote sensing techniques have been used to assess land use and land cover change detection in Rumuruti [14], Nyando Wetland [15], Tana River Basin [16], and Ombeyi Wetland [17] among other large wetlands. These studies cumulatively indicated that the landscape of Kenya's wetlands is actively transforming due to human-induced factors.

Kenya's wetland areas are estimated to cover a landmass of between 3\% - 4\% which translates to about $14,000 \mathrm{~km}^{2}$ [18]. The National Environment Management Authority (NEMA-Kenya) reported that Kenya's wetland areas have declined from $4 \%$ cover to $2 \%$ mainly due to population pressure [19]. The rapidly increasing population in Kenya has led to the competing land uses and over-utilization of these fragile ecosystems through wetland reclamation for construction of infrastructural facilities, commercial forestry establishment and agricultural operations among others [19] [20]. Over the last fifty years, these anthropogenic impacts have hastened ecological change and exacerbated land degradation challenges to the existing wetland resources in Kenya, putting their ability to continue providing essential ecological services under substantial threat [1]. Future protection and sustainable management of these fragile ecosystems require insights that can inform policy and decision-makers [21]. However, information on the scale of ecological changes in wetlands in Kenya is still inconclusive since previous research and management efforts were majorly focused on urban-based wetlands, those along major watercourses and designated Ramsar sites, neglecting the community-based wetlands [1] such as the Kapkatet which mostly support rural livelihoods. To conserve and safeguard Kenyan wetlands resources, it is necessary to monitor all wetlands and their associated land features. Therefore, this study aimed at assessing the trends of land use and land cover changes in Kapkatet Wetland between 1986 and 2019 and their driving forces. This research is designed to provide insights that can aid decision-making for effective restoration and conservation of this wetland resource.

\section{Materials and Methods}

\subsection{Study Area}

Kapkatet wetland is a community-based wetland which is located in the South 
Rift region and serves as an important landmark separating Bomet and Kericho Counties in Kenya (Figure 1). It lies on an altitude of 1,957 meters with geographic coordinates of Latitudes $0^{\circ} 38^{\prime} 59^{\prime \prime S}$ and Longitude $35^{\circ} 11^{\prime} 23^{\prime \prime} \mathrm{E} \& 35.2^{\circ} \mathrm{E}$ [22]. It also serves as the headwaters of the Kipsonoi River, an important tributary draining its water to Lake Victoria. The rainfall pattern in the region is evenly distributed with annual averages ranging between $1000 \mathrm{~mm}$ and 1400 $\mathrm{mm}$; and temperatures ranging from $16^{\circ}$ to $24^{\circ}$ [23]. According to Census carried out in 2009, Kapkatet wetland is estimated to be supporting a population of more than 34,684 residents [24] who rely on its goods and services. This wetland is rich in various macrophytes with predominant vegetation being Cyperus spp. and Polygonum spp and many other non-woody plants both emergent and submerged. Surprisingly, most of the natural vegetation at the edges has extensively been replaced with exotic trees, paddocks, and a span of crop fields in other sections. Reeds have over time been utilized by locals for roofing, making sheds for crop nurseries, and tea nurseries for Kapkatet factory amongst other uses. The soil composition is mostly alluvial clays which are fertile and supports myriads of anthropogenic activities like crop cultivation and are also used for brick making. Moreover, this ecosystem serves as a historic site where most of the Kalenjin cultural activities and festivals are undertaken. Besides, several organisms, both terrestrial and aquatic, inhabit this wetland. A very good example of birds common in this wetland is the endangered grey crowned crane (Balearica regulorum) who nest and glean on varieties of food substrates available on the subsurface of this wetland. Predominant land use activity surrounding the

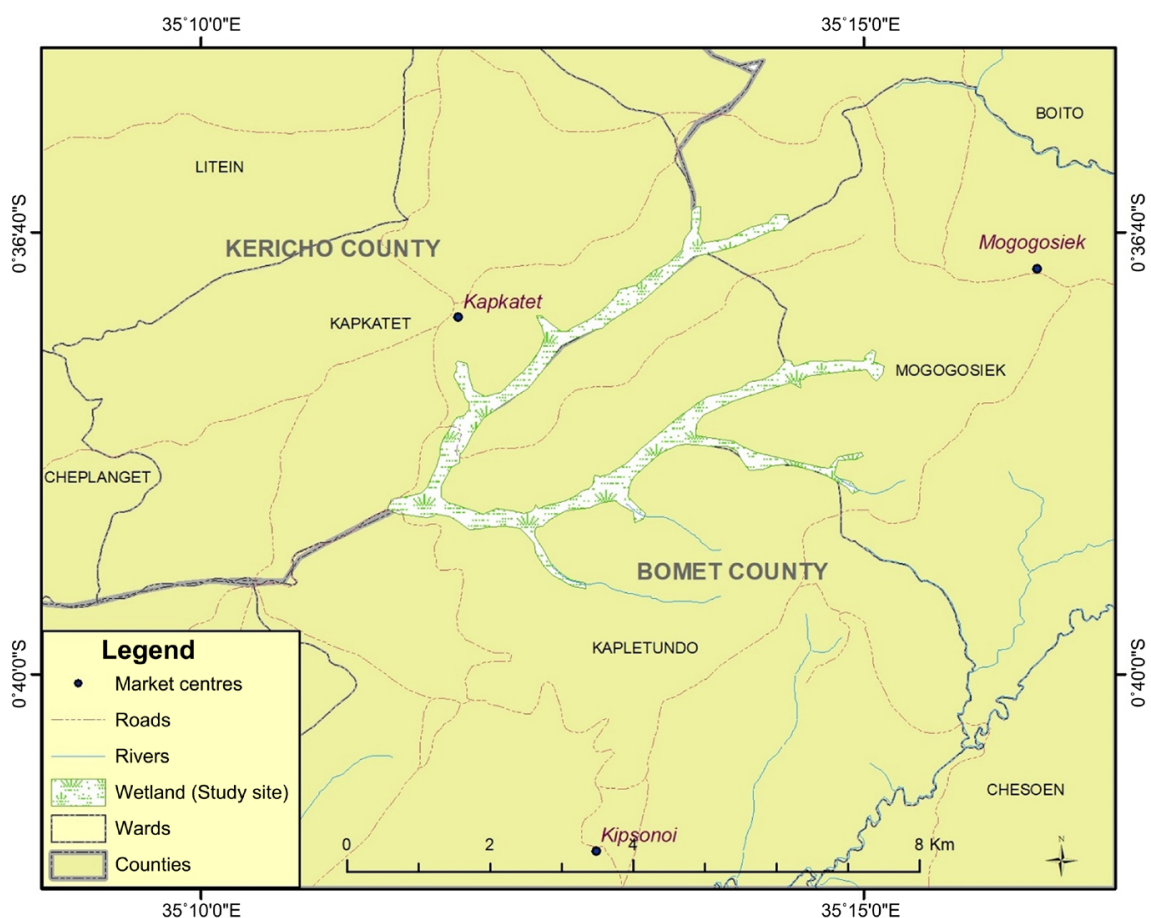

Figure 1. Map showing locations of bomet and kericho counties where Kapkatet wetland is located (Source: Author). 
wetland is farming, tea farming (Camellia sinensis) being a major cash crop though some engage in small-scale horticultural farming. Tea plantations and exotic trees are common along the periphery of this wetland. High market demand for wood fuel mainly by Litein and Kapkatet Tea Factories and several institutions and hotels located within Kapkatet Town has triggered plantation of fast-growing eucalyptus trees on or at a proximity to the wetland. In addition to this, erratic rainfalls in the recent past have further contributed to the high dependence rate on wetland products by the locals.

\subsection{Research Methods}

\subsubsection{Remote Sensing Analysis}

To evaluate the spatiotemporal dynamics of land use land cover changes (LUCCC) in Kapkatet wetland, imageries for the years 1986 (Landsat 4-5 TM), 2000 (Landsat 7 ETM+), and 2019 (SENTINEL) were obtained from USGS/ESA databases. All the acquired images were referenced to the Kenyan Coordinate System using UTM projections and WGS 84 datum on Arc GIS 10.2 software. Considerations made while obtaining these images were on seasons over which they were captured. Only those of dry seasons across the three years were utilized in this study. This is because during dry seasons, there is minimal cloud cover hence higher precision, and also various anthropogenic activities are rampant particularly on the wetland during such periods [25].

Pre-processing and processing activities of Landsat and Sentinel images were done using Arc GIS 10.2. This involved the process of geometric image correction for clarity over the identified periods (1986, 2000 \& 2019). For digital image processing, false colour composites were created using bands 2,3 , and 4 for each of the images. The images were then geo-referenced in the UTM projection WGS84-reference ellipsoid. GIS data which consisted of Global Positioning System (GPS) ground-truthing data were entered into ArcGis 10.2 software. Supervised classification of the satellite imagery was used to produce land use wetland cover classes. The maximum likelihood classification technique was performed using the spectral bands 2,3 , and 4 in each of the satellite images. Feature extraction, selection of training data, and selection of suitable classification approaches were carried out to generate each of the wetland cover classes of the study area. Accuracy assessment was achieved by comparing samples of pixels from the classification results and the ground-truthing data collected using a GPS machine from the field.

Overall accuracy was calculated by dividing the number of pixels for a particular class with the overall number of reference pixels for that particular class. To derive the information on the wetland cover and wetland change over these three periods, four distinct classes (Table 1) were only chosen from the wetland regions. They were selected based on observable features identified in the photographs captured during the field survey and ground-truthing exercise. Post classification comparison method was used for change detection whereby images of different dates were first classified and labelled individually and the classified 
Table 1. Wetland cover classes.

\begin{tabular}{cl}
\hline Wetland Cover Classes & \multicolumn{1}{c}{ Description } \\
\hline Tree Cover & $\begin{array}{l}\text { Composed of both hardwood and softwood trees planted within the } \\
\text { wetland buffer region, along the edges, or on the wetland area }\end{array}$ \\
Papyrus reeds & $\begin{array}{l}\text { Non-woody plants which are either emergent or submerged and grows } \\
\text { within the wetland }\end{array}$ \\
Open grounds & $\begin{array}{l}\text { A section on the wetland with scattered patches of wetland vegetation or } \\
\text { non-woody trees or/and section converted to cropland, grassland, or } \\
\text { alien vegetation }\end{array}$ \\
$\begin{array}{c}\text { Disturbed Papyrus } \\
\text { reeds/wetland vegetation }\end{array}$ & \begin{tabular}{l} 
Partially/completely burnt or trimmed wetland vegetation \\
\hline
\end{tabular}
\end{tabular}

images were then compared and changed areas extracted. An error matrix method was used to check for classification accuracy. All the other computations were done using ArcGIS 10.4 software. Variations in terms of wetland cover classes were deduced from the findings with varying percentages of classes over the past three decades. Computation for wetland area change over the periods (1986-2019) was done using the following method;

$$
\% \Delta=\frac{\text { Wetland area } \Delta(2019-1986)}{\text { Original Wetland area }(1986)} \times 100
$$

where; $\% \Delta$ is Percentage Change.

\subsubsection{Descriptive Survey}

Household Survey: Both structured and semi-structured questionnaires were used to obtain information on the drivers of wetland encroachment. The purposive sampling technique was adopted to identify households located within a radius of $\leq 1 \mathrm{~km}$ from the wetland and those whose parcels of land extend to this wetland. Because of time and resources, respondents $(n=100)$ consisting of an adult in each of the identified households, willing and capable of providing the required information, were allowed to fill in the questionnaires with the help of two trained field assistants. According to the gender disparities, 69 were male and 31 were female drawn from the two counties. In cases where an adult was not available or not willing to be interviewed, the next household was chosen. The data from the household survey were entered and coded using SPSS software and thereafter, quantitative data subjected to descriptive statistics to obtain frequencies and percentages.

Focused Group Discussions (FGDs): This study utilised four FGDs, three in Bomet County (Chesilyot, Togomin and Cheptangulgei Villages) and one in Kericho County (Rungut village). The number of FGDs was higher in Bomet County, because a larger portion of the wetland is located in this county. The villages selected represented the entire region of the study area. A total of 40 residents participated in the four FGDs consisting of youths, local leaders and outstanding men and women in the community. The researcher liaised with both the village elder and the assistant chiefs in finding suitable places for hold- 
ing these discussions. Moderators were chosen to guide the discussions.

\section{Results and Discussion}

\subsection{Classification and Distribution of LULC Changes in Kapkatet Wetland}

Four classes of LULC were identified in the study area. The classified LULC maps of 1986, 2000, and 2019 (Figure 2) show that the wetland is characterized by tree cover, reeds/papyrus, open ground, and disturbed reeds/papyrus. The areal distribution of these four LULC classes concerning time was determined and presented in Table 2 . The results revealed that with regards to total surface area coverage, reeds/papyrus was the largest with $2,362,500 \mathrm{~m}^{2}$, followed by tree cover $\left(431,100 \mathrm{~m}^{2}\right)$, open ground $\left(354,600 \mathrm{~m}^{2}\right)$, and finally disturbed reeds/papyrus $\left(328,500 \mathrm{~m}^{2}\right)$. The total surface area of the wetland was found to be $3,476,700 \mathrm{~m}^{2}$.

\subsection{Spatial-Temporal Trends and Change Detection}

The study results (Table 2) indicated that LULC types in the Kapkatet Wetland have undergone significant transformation over the years.

\subsubsection{Reeds/Papyrus}

The coverage of reeds/papyrus in $1986\left(2,362,500 \mathrm{~m}^{2}\right)$ was higher than the one for the year $2019\left(1,349,400 \mathrm{~m}^{2}\right)$, showing a loss over time. The coverage of this

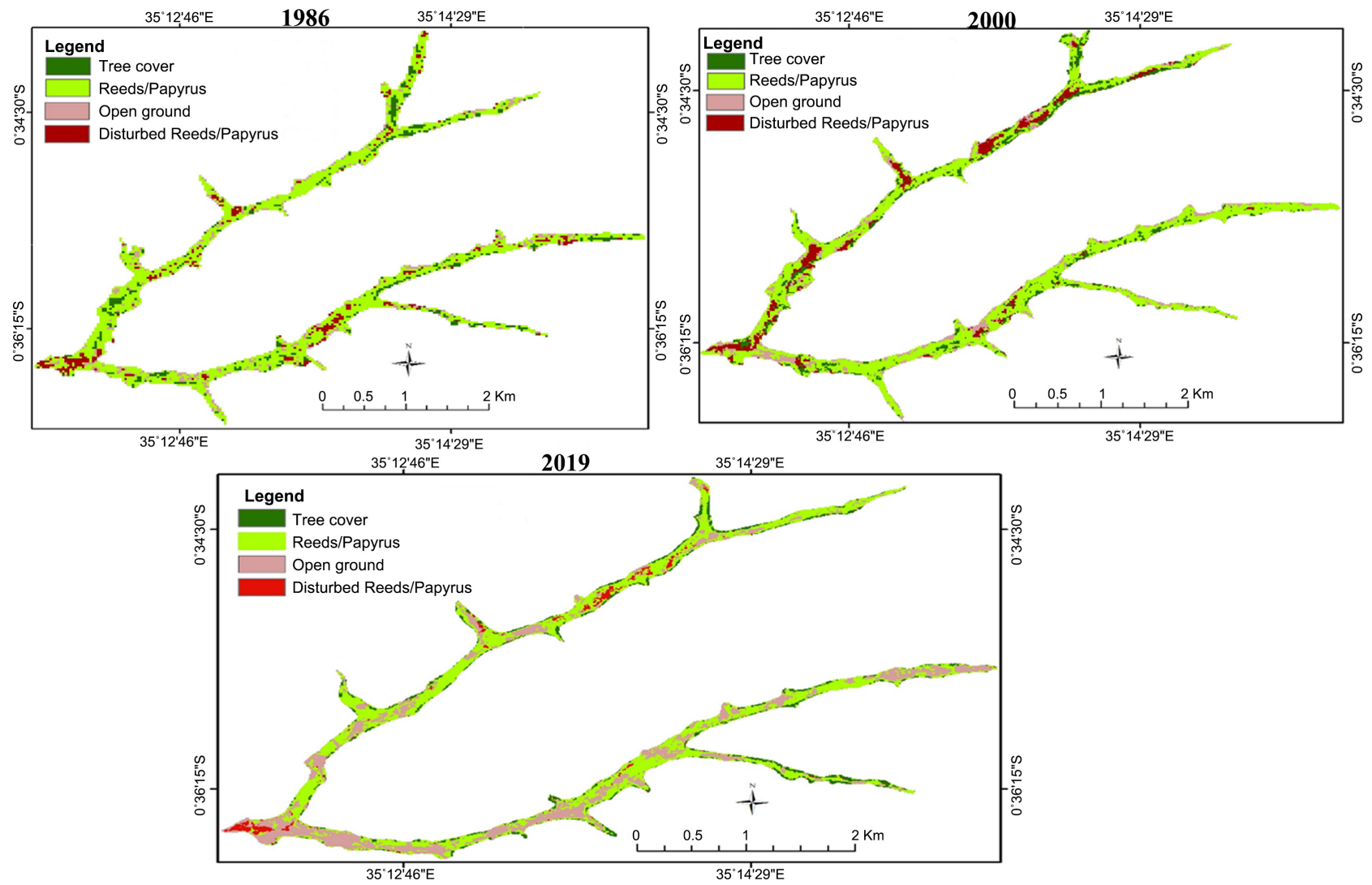

Figure 2. Masked land use/cover maps for the years 1986, 2000 \& 2019. 
Table 2. Changes of land use/cover area (\%) and computations of annual changes for the period 1986-2019.

\begin{tabular}{|c|c|c|c|c|c|c|c|c|}
\hline \multirow{3}{*}{ Wetland Use/Cover } & \multicolumn{6}{|c|}{ Area (sq. m) } & \multicolumn{2}{|c|}{ \% Change } \\
\hline & \multicolumn{2}{|c|}{1986} & \multicolumn{2}{|c|}{2000} & \multicolumn{2}{|c|}{2019} & \multirow[b]{2}{*}{ (\%) $\Delta 1986-2000$} & \multirow[b]{2}{*}{ (\%) $\Delta 2000-2019$} \\
\hline & & $(\%)$ & & (\%) & & $(\%)$ & & \\
\hline Tree Cover & 431,100 & 12 & 409,950 & 13 & 275,500 & 11 & $1 \%$ & $-3 \%$ \\
\hline Reeds/Papyrus & $2,362,500$ & 68 & $1,950,300$ & 63 & $1,349,400$ & 52 & $-5 \%$ & $-11 \%$ \\
\hline Open Ground & 354,600 & 10 & 395,780 & 13 & 889,300 & 34 & $3 \%$ & $21 \%$ \\
\hline Disturbed Reeds/Papyrus & 328,500 & 9 & 339,750 & 11 & 101,300 & 4 & $2 \%$ & $-7 \%$ \\
\hline TOTAL & $3,476,700$ & 100 & $3,095,780$ & 100 & 2615,500 & 100 & & \\
\hline
\end{tabular}

LULC has been on a decreasing trend for the last three decades, decreasing by $5 \%$ between 1986 and 2000 and further by $11 \%$ from 2000 to 2019 . The population of the Kapkatet region just like any other part of the country has been the major driver which contributed to the change. Demand for more food by this population has necessitated the expansion of farming lands, thus contributing to the degradation of wetland vegetations. [26] also reported a similar trend in their study where there was a loss of papyrus in Dunga (50\%), Koguta (47\%), and Kusa (34\%) between the years 1964 and 2000. An elderly participant during an FGD in Chesilyot village reported having been observing a declining trend of birds scavenging on this wetland over the past three decades. This is an indirect parameter that could be linked to the decline in reeds/papyrus cover. Planting non-native vegetations like eucalyptus trees could also be attributed to the decline in papyrus/reeds cover. [27] acknowledged that eucalyptus species planted on riparian zones have invasive characteristics that alter with the floristic diversity, stand structure and the diversity of wetland vegetations.

\subsubsection{Tree Cover}

Similar to reeds/papyrus, tree coverage initially recorded in $1986\left(431,100 \mathrm{~m}^{2}\right)$ was determined to be higher than the one recorded for $2019\left(275,500 \mathrm{~m}^{2}\right)$, an indication of tree cover loss. From 1986 to 2000, tree cover marginally increased by $1 \%$ before eventually decreasing by $3 \%$ between 2000 and 2019. The most predominant exotic vegetations along the periphery of this wetland are the eucalyptus trees. Owing to its fast growth and market demand forces, eucalyptus farming in this area is becoming a lucrative business. The external market demand from mushrooming industries such as the Kenya Tea Development Authority (KTDA) owned factories namely, Kapkatet, Litein, Chelal and Tebesonik; private tea factories like Korara and Bureti tea factories mainly rely on the locals for the supply of firewood [28]. This explains why there was a decrease in tree cover between the years 2000 and 2019. Additionally, in recent years the government through its devolved function of the environment has reinstated and enforced the 2009 regulations on the use and management of wetlands, riverbanks, lakeshores and seashores [23]. 


\subsubsection{Open Ground}

The coverage of open grounds however has been increasing over the years. The coverage in $1986\left(354,600 \mathrm{~m}^{2}\right)$ was found to be lower than the coverage for 2019 $\left(889,300 \mathrm{~m}^{2}\right)$, hence an increased open ground. Generally, open ground recorded a $3 \%$ increased coverage between 1986 and 2000 and a further $21 \%$ increased coverage from 2000 and 2019. The expansion of open grounds was noted to be as a result of crop cultivation and burning of wetland vegetations especially during dry seasons as part of the pre-fallowing process engaged by some of the residents whose lands extend to this wetland. Zones adjacent to the wetland were also found out to be dominated by exotic trees, tea bushes or horticultural farms, a similar feature reported by [22] on this wetland. This is an indication that natural vegetations which initially dominated the watershed areas were destroyed and replaced by exotic species including crops.

\subsubsection{Disturbed Reeds/Papyrus}

The extent of coverage of the papyrus and reeds experienced a percentage change from $-5 \%$ between the years 1986 and 2000 to a percentage change of $-11 \%$ in the periods between 2000 and 2019 . This change is attributable to the increased percentage change of open grounds from 3\% (1986-2000) to $21 \%$ (2000-2019) which accounted for the decline in the papyrus and reeds. This indicates that this wetland has over time been encroached hence affecting the spatial extent of the vegetation cover in the wetland. Anthropogenic activities carried out in the area have also greatly contributed to the dwindling of this wetland. An elderly man during FGD in Chesilyot Village highlighted that it was a norm in the community to undertake cultural festivals for example, initiation ceremonies which were conducted annually around December in specific localities within this wetland. Also, he further mentioned that initiates used to construct their huts using reeds and twigs sourced from the wetland. There was a need therefore to preserve this ecosystem which comprehends what was observed through satellite imageries where reeds covered a higher percentage (68\%) as compared with open grounds and the disturbed reeds that covered $10 \%$ and $9 \%$ respectively.

\subsection{Drivers of Encroachment in Kapkatet Wetland}

The probable drivers of wetland encroachment were based on the respondents' perceptions and ranked by frequencies of listed stressors as shown in Figure 3. However, the most significant drivers have been discussed as follows;

\subsubsection{Land Conversion}

Study results indicated that $49 \%(\mathrm{n}=100)$ of the respondents perceived land conversion as an impetus of wetland encroachment in the study area. Field visits undertaken during dry periods were a true manifestation of how rapidly this wetland was being converted for economic use. Wetland vegetations especially papyrus reeds were being burnt by different landowners in favour of the growth of non-perennial crops, livestock grazing fields, the establishment of woodlots, 


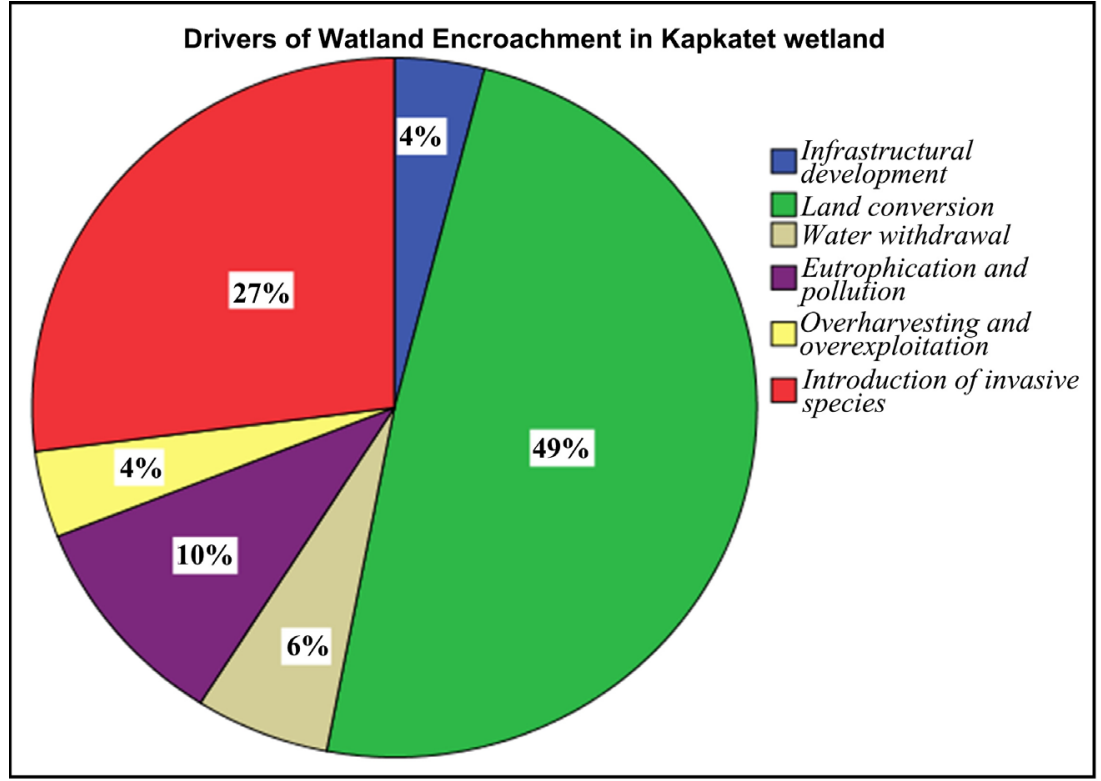

Figure 3. Anthropogenic activities contributing to wetland encroachment.

fish ponds and harvesting of soils for brick-making. These findings were similar to what was reported in the Nyando Wetland where such economic activities eventually contributed to the loss of its biodiversity, altered fish breeding grounds and bird habitats [29]. Horticultural farming in some sections of the wetland was also noticeable with the majority of the FGD participants claiming the availability of water and fertile soils in such areas during dry periods as motivation for farming. This is in line with the study conducted by [30] who also found out that the major reasons for wetlands degradation in Tanzania were a result of population pressure that led to the demand for more agricultural land. Studies conducted in Tempisque Basin by Daniels \& Cumming [31] also showed that demand for more land contributed to the conversions of the wetland in areas where they were most accessible and unprotected.

\subsubsection{Introduction of Invasive Species Plants}

On the drivers of encroachment, 27\% $(n=100)$ of the respondents indicated the introduction of invasive species as a factor of encroachment. Most of those who had lived in the area for more than 20 years $(76 \%, n=100)$, stated that vegetation on this wetland indeed had changed over the past decades. Furthermore, during FGD discussions, one of the participants who happened to be elderly noted also that papyrus reeds which initially were dense, are now in patches with grass, exotic trees, and shrubs taking over the entire wetland region. This information buttressed the findings from satellite imageries that showed that wetland size and vegetations have declined in the past three decades. This finding is also consistent with that of [32] who noted that the introduction of invasive species was one of the drivers of wetland change. A similar problem was also experienced in the riparian zones of the Western Cape of South Africa where eucalyptus among other invasive species led to the degradation of the wetland [27] 
[33]. The ability of eucalyptus trees to alter the vegetation structure and wetland hydrology has also contributed to the reduction of food resources for the avifauna in the area. The allelopathic nature attributed to eucalyptus comes with new ecological niches which appear to be benefiting alien species over the native ones. Invasion of wetland grasses was also noticeable in some parts of the wetland due to the increased use of NPK fertilisers by tea farmers. This corroborates with the findings by [22] [34].

\subsubsection{Eutrophication and Pollution}

Eutrophication especially in Sub-Saharan Africa poses a threat to surface waters including wetland ecosystems. According to the household respondents, 10\% (n $=100$ ) attributed this factor as among the drivers of wetland encroachment in the area, citing that indeed some of the residents have established tea plantations along the periphery of this wetland. The majority of the farmers in the area engage in tea farming [23] which requires a constant supply of fertilizers containing supplements of nitrogen, phosphorus, and potassium (NPK). Considering the terrain and drainage pattern in the area, often much of the runoffs from these farms laden with traces of NPK find their way to the wetland, changing its vegetation regime [22] found out the $\mathrm{pH}$ levels on this wetland were low, a factor which he attributed to high levels of chemicals especially nitrogen and phosphorus emanating from the adjacent tea farms. Dissolved wastes from livestock droppings while grazing on the wetland vegetations also contributed significantly to eutrophication in this area [22] [35]. The findings are also consistent with those of [36] who indicated that Las Tablas de Daimiel wetland has been impaired by eutrophication, salinisation and pollution as a result of discharging municipal and agricultural wastes toward the wetland. Siltation due to marram road was observed in sections close to a footbridge heading to Kapletundo Ward which had converted a section of the wetland into a field. It was further observed that solid wastes carried by water runoffs from Kapkatet Town were being deposited on the site which is attributed to the continued decline in wetland species. Car washing activities were also highlighted by one of the FGD participants at Chesilyot as a major contributor to water pollution. Laboratory analysis of water from Daraja Sita, a section on this wetland, showed that it had high conductivity rates than all the other sampled areas [22].

\section{Conclusion}

Results show a dwindling trend of wetland cover over the past thirty-three years (1986-2019). Arrays of anthropogenic activities were found out to have contributed to the wetland loss with the land conversion for agricultural purposes being the most dominant economic driver of encroachment. Different classes used to deduce the changing pattern indicated variations with open grounds depicting an increasing trend within the selected periods. Considering that the wetland is purely communally owned, private landowners whose lands extend to the wetland have resorted to utilizing their parcels in different ways with the majority 
converting them into paddocks and crop farms for subsistence use. This act has therefore left the ecosystem vulnerable with minimal interventions from both the local and national government. Emerging land-use pressures coupled with weak environmental laws in such areas will continue to put pressure on this ecosystem with solutions lying on quick intervention from establishing community-based resource management committees whose responsibilities will be to oversee their utilization and advice accordingly on the need for conservation. County governments, on the other hand, should develop resource inventory that will ensure up-to-date data of all the resources available which can as well be utilized for informed decision making.

\section{Acknowledgements}

This is part of the research dissertation submitted to the Pan African University Institute of Life and Earth Sciences (PAULESI), University of Ibadan, Nigeria. I duly acknowledge and thank those who contributed either by improving or reviewing this paper.

\section{Conflicts of Interest}

The authors declare no conflicts of interest regarding the publication of this paper.

\section{References}

[1] Okeyo-Owuor, J.B., Raburu, P.O., Masese, F.O. and Omari, S.N. (2012) Wetlands of Lake Victoria Basin, Kenya: Distribution, Current Status and Conservation Challenges. Community-Based Approach to the Management of Nyando Wetland, Lake Victoria Basin, Kenya, 1.

[2] Millennium Ecosystem Assessment, M.E.A. (2005) Millennium Ecosystem Assessment: Ecosystems and Human Well-Being. Island Press, Washington DC.

[3] Ajibola, M.O., Adeleke, A.M., Ogungbemi, O.A. and Ogungbemi, A.O. (2016) An Assessment of Wetland Loss in Lagos Metropolis, Nigeria. Developing Country Studies, 6, 1-7.

[4] Prigent, C., Papa, F., Aires, F., Jimenez, C., Rossow, W.B. and Matthews, E. (2012) Changes in Land Surface Water Dynamics since the 1990s and Relation to Population Pressure. Geophysical Research Letters, 39, L08403. https://doi.org/10.1029/2012GL051276

[5] Oguttu, H.W., Bugenyi, W.F., Leuenberger, H., Wolf, M. and Bachofen, R. (2008) Pollution Menacing Lake Victoria: Quantification of Point Sources around Jinja Town, Uganda. Water SA, 34, 89-98. https://doi.org/10.4314/wsa.v34i1.180865

[6] Coppin, P., Jonckheere, I., Nackaerts, K., Muys, B. and Lambin, E. (2004) Review Article Digital Change Detection Methods in Ecosystem Monitoring: A Review. International Journal of Remote Sensing, 25, 1565-1596. https://doi.org/10.1080/0143116031000101675

[7] Muro, J., Canty, M., Conradsen, K., Huttich, C., Menz, G., Nielsen, A.A., Skriver, H., Strauch, A. and Thonfeld, F. (2016) Identification of Dynamic Cover Types in Wetlands by Using Multitemporal Cross-Polarized Sentinel-1 Images. ESA Living Planet Symposium 2016, Prague, 9-13 May 2016, p. 1. 
[8] Haque, M.I. and Basak, R. (2017) Land Cover Change Detection Using GIS and Remote Sensing Techniques: A Spatio-Temporal Study on Tanguar Haor, Sunamganj, Bangladesh. The Egyptian Journal of Remote Sensing and Space Science, 20, 251-263. https://doi.org/10.1016/j.ejrs.2016.12.003

[9] Kharazmi, R., Tavili, A., Rahdari, M.R., Chaban, L., Panidi, E. and Rodrigo-Comino, J. (2018) Monitoring and Assessment of Seasonal Land Cover Changes Using Remote Sensing: A 30-Year (1987-2016) Case Study of Hamoun Wetland, Iran. Environmental Monitoring and Assessment, 190, 1-23.

https://doi.org/10.1007/s10661-018-6726-Z

[10] Suresh, M., Tiwari, A. and Naraiah, R. P. (n.d.) Change Detection and Estimation of Change Analysis Using Satellite Images.

[11] Papastergiadou, E.S., Retalis, A., Apostolakis, A. and Georgiadis, T. (2008) Environmental Monitoring of Spatio-Temporal Changes Using Remote Sensing and GIS in a Mediterranean Wetland of Northern Greece. Water Resources Management, 22, 579-594. https://doi.org/10.1007/s11269-007-9179-7

[12] Kesikoglu, M.H., Atasever, U.H., Dadaser-Celik, F. and Ozkan, C. (2019) Performance of ANN, SVM and MLH Techniques for Land Use/Cover Change Detection at Sultan Marshes Wetland, Turkey. Water Science and Technology, 80, 466-477. https://doi.org/10.2166/wst.2019.290

[13] Orimoloye, I.R., Mazinyo, S.P., Kalumba, A.M., Nel, W., Adigun, A.I. and Ololade, O.O. (2019) Wetland Shift Monitoring Using Remote Sensing and GIS Techniques: Landscape Dynamics and Its Implications on Isimangaliso Wetland Park, South Africa. Earth Science Informatics, 12, 553-563. https://doi.org/10.1007/s12145-019-00400-4

[14] Mwita, E.J. (2013) Land Cover and Land Use Dynamics of Semi-Arid Wetlands: A Case of Rumuruti (Kenya) and Malinda (Tanzania). Journal of Geophysics and Remote Sensing, S1, 1. https://doi.org/10.4172/2469-4134.S1-001

[15] Okotto-Okotto, J., Raburu, P.O., Obiero, K.O., Obwoyere, G.O., Mironga, J.M., Okotto, L.G. and Raburu, E.A. (2018) Spatio-Temporal Impacts of Lake Victoria Water Level Recession on the Fringing Nyando Wetland, Kenya. Wetlands, 38, 1107-1119. https://doi.org/10.1007/s13157-016-0831-y

[16] Langat, P.K., Kumar, L. and Koech, R. (2019) Monitoring River Channel Dynamics Using Remote Sensing and GIS Techniques. Geomorphology, 325, 92-102. https://doi.org/10.1016/j.geomorph.2018.10.007

[17] Nicodemus Osoro, O., Obade, P. and Gathuru, G. (2019) Anthropogenic Impacts on Land Use and Land Cover Change in Ombeyi Wetland, Kisumu County, Kenya. International Journal of Regional Development, 6, 57. https://doi.org/10.5296/ijrd.v6i1.15292

[18] Ministry of Environment and Mineral Resources, MENR (2012) Kenya Wetlands Atlas. Ministry of Environment and Mineral Resources.

[19] Gok. (2006) EU Kenya Country Environment Profile.

[20] Mulei, J.M., Onkware, A.O. and Otieno, D.F. (2016) Vegetation Community Structure and Diversity in Swamps Undergoing Anthropogenic Impacts in Uasin Gishu County, Kenya. African Journal of Ecology and Ecosystems, 3, 175-184.

[21] Kansiime, F., Saunders, M.J. and Loiselle, S.A. (2007) Functioning and Dynamics of Wetland Vegetation of Lake Victoria: An Overview. Wetlands Ecology and Management, 15, 443-451. https://doi.org/10.1007/s11273-007-9043-9

[22] Angima, M., Akama, J., Getabu, A. and Omondi, A. (2020) Assessment of Spa- 
tio-Temporal Variation of Selected Physico-Chemical Properties of Kapkatet Wetland, Kericho County, Kenya.

[23] (2018) County Government of Bomet County Integrated Development Plan.

[24] KNBS (2009) 2009 Kenya Population and Housing Census. An Analytical Report on Housing Conditions, Amenities and Household Assets: Vol. XI (Issue March).

[25] Theau, J. (2011) Change Detection. In: Springer Handbook of Geographic Information, Springer, Berlin, 75-94. https://doi.org/10.1007/978-3-540-72680-7 7

[26] Owino, A.O. and Ryan, P.G. (2007) Recent Papyrus Swamp Habitat Loss and Conservation Implications in Western Kenya. Wetlands Ecology and Management, 15, 1-12. https://doi.org/10.1007/s11273-006-9001-y

[27] Tererai, F., Gaertner, M., Jacobs, S.M. and Richardson, D.M. (2013) Eucalyptus Invasions in Riparian Forests: Effects on Native Vegetation Community Diversity, Stand Structure and Composition. Forest Ecology and Management, 297, 84-93. https://doi.org/10.1016/j.foreco.2013.02.016

[28] Oballa, P.O., Konuche, P.K.A., Muchiri, M.N. and Kigomo, B.N. (2010) Facts on Growing and Use of Eucalyptus in Kenya. Kenya Forestry Research Institute, Nairobi, 30 p. https://doi.org/10.1007/s00330-014-3569-Z

[29] Masese, F.O., Raburu, P.O. and Kwena, F. (2008) Threats to the Nyando Wetland. In: Community Based Approach to the Management of Nyando Wetland, Lake Victoria Basin, Kenya, Kenya Disaster Concern \& VIRED International \& UNDP, Nairobi, $68-80$.

[30] Munishi, P.K.T., Rweyemamu, R., Kideghesho, J.R. and Kilungu, H.H. (2012) The Role of Bahi Swamp Wetlands in Enhancing Household Food Security and Income of Adjacent Communities. Tanzania Journal of Forestry and Nature Conservation, 81, 115-132.

[31] Daniels, A.E. and Cumming, G.S. (2008) Conversion or Conservation? Understanding Wetland Change in Northwest Costa Rica. Ecological Applications, 18, 49-63. https://doi.org/10.1890/06-1658.1

[32] Galatowitsch, S.M. (2018) Natural and Anthropogenic Drivers of Wetland Change. In: The Wetland Book II: Distribution, Description, and Conservation, Springer Nature, Berlin, 359-367. https://doi.org/10.1007/978-94-007-4001-3 217

[33] Forsyth, T. (2004) Critical Political Ecology: The Politics of Environmental Science. Routledge, London. https://doi.org/10.4324/9780203017562

[34] Maurer, D.A. and Zedler, J.B. (2002) Differential Invasion of a Wetland Grass Explained by Tests of Nutrients and Light Availability on the Establishment and Clonal Growth. Oecologia, 131, 279-288. https://doi.org/10.1007/s00442-002-0886-8

[35] Murakaru, J.M. (2010) Seasonal Changes in Physico-Chemical Status and Algal Biomass of Lake Naivasha, Kenya. Kenyatta University, Nairobi.

[36] Álvarez-Cobelas, M., Sánchez-Carrillo, S., Cirujano, S. and Angeler, D.G. (2010) A Story of the Wetland Water Quality Deterioration: Salinization, Pollution, Eutrophication and Siltation. In: Ecology of Threatened Semi-Arid Wetlands, Springer, Berlin, 109. https://doi.org/10.1007/978-90-481-9181-9 5 